\title{
Investment Promotion in the South African Manufacturing INDUSTRY: INCENTIVE COMPARISONS WITH MALAYSIA AND SINGAPORE
}

\author{
Martha Susanna Isabella Wentzel and Maxi Steyn \\ College of Accounting Sciences, UNISA
}

Accepted: February 2014

\begin{abstract}
South Africa needs to increase its inward foreign direct investment (FDI) in order to achieve economic growth. The purpose of this article is to explore which interventions could be launched in the short term to enhance the country's attractiveness for foreign investors. The findings of the literature review demonstrated that incentives, as a determinant of investment, are the short-term intervention with the most significant potential to attract additional FDI. A comparative study, which provided insight into the incentives that are currently offered to the manufacturing sectors of three countries (South Africa, Malaysia and Singapore), assisted in identifying two additional incentives that the South African government could introduce and three existing incentives that could be amended. The introduction or modification of these incentives could ensure that South Africa has a competitive advantage to attract investment from foreign investors and thereby increase its inward FDI in the manufacturing industry.
\end{abstract}

Key words: foreign direct investment, manufacturing, incentives, investment in capital assets, incentives that reduce investors' fiscal burden

JEL: D92, K34, O14, O23

\section{1}

\section{Introduction and research objectives}

"Investment is crucial to growth. It's what makes economies successful" (Hazelhurst, 2011). This statement by the South African Finance Minister Pravin Gordhan supports government's objective of building South Africa's economic capacity and promoting investment (National Treasury, 2009:2). Investment provides employment opportunities, innovations in the goods and services available to consumers and a competitive edge for the national economy. Foreign direct investment (FDI) has an additional attribute, namely the flow of capital beyond country borders in search of the highest risk-adjusted return. This process provides economic benefits to the host and home countries (Conference Board of Canada, 2004:1).

The South African government acknowledges the importance of FDI in facilitating the growth of the country's economy. During 2007, then Finance Minister Trevor Manuel (National Treasury, 2007:9) stated that "policy reforms will raise investment growth rates, pulling in higher levels of FDI". The National Treasury later confirmed the significance of FDI, stating that, as a low-savings developing economy, with high domestic investment requirements, South Africa needs to attract FDI in order to support domestic investment financing requirements (National Treasury, 2011:iii).

In 2011, however, Finance Minister Pravin Gordhan admitted that the government "may not have done enough" to promote FDI (Hazelhurst, 2011). The 2012 World Investment Report also mentioned that South Africa should be attracting higher levels of FDI based on the country's FDI potential (UNCTAD, 2012:xv, 32).

To explore whether there are potential development focus areas which could assist in increasing South Africa's FDI, one of the key determinants that influence foreign direct investors' decision in choosing an investment location, namely incentives, were investigated. The qualitative research was performed by means of a literature review, where incentives currently provided by South Africa and two 
comparable foreign countries, namely Malaysia and Singapore, were identified. A comparative study was then done where the incentives provided by these three countries were compared and analysed. This comparison focused on the incentives provided to the manufacturing sector specifically, as this sector contributes significantly to the South African economy (Wentzel, 2010:5-7). The aim of this comparative study was to determine whether there are additional incentives that South Africa can initiate, or existing incentives that can be amended, which will ensure that the country has a competitive advantage for attracting foreign investors. The introduction or modification of these incentives could increase South Africa's inward FDI and assist in the country's economic growth.

This article first analyses South Africa's current status as a potential FDI destination and the key determinants for attracting FDI are briefly considered. This is followed by a discussion of incentives (one of the key determinants) specifically as a short-term intervention to attract additional FDI. Thereafter, the results from the comparison between incentives provided by the three countries are discussed and potential future development focus areas are identified which could increase South Africa's attractiveness as an FDI destination.

2

\section{Literature overview}

\subsection{The current status of South Africa as a potential investment destination}

Developed and developing countries all over the world are increasingly recognising FDI as an important instrument of economic growth for the host country (Asafo-Adjei, 2007:91). Kamath (2008:35) argues that the growth of the economy can be enhanced by FDI because it "has a positive impact on exports, imports and has greatly contributed to GDP". Increased FDI can give rise to several benefits for the host country. Besides bringing in capital, it facilitates the transfer of technology and technical assistance, as well as the development of domestic industrial infrastructure. Other benefits could include increased tax revenue for the host country, employment creation, regional expansion or development and an increase in foreign exchange reserves (Tuomi, 2009:7-10). Some studies have confirmed that the host country does indeed benefit from FDI. Higon and Vasilakos's (2011:663) research determined that the British retail sector has received positive FDI spillovers. Although FDI on the African continent at large has been found to have lower impact in terms of linkages and spill-over into the domestic economy compared to global standards (mainly due to a concentration of FDI into resource rather than manufacturing as well as political instability on the continent (UNIDO, 2013:3)), Fedderke and Romm (2005:738) reported a direct positive impact on economic growth from FDI specifically in the case of South Africa.

The 2012 World Investment Report (UNCTAD, 2012:190) reflects South Africa's actual inward FDI by providing the value of greenfield (new) FDI projects. In 2008 this value was $\$ 13533$ million, but it declined to $\$ 7695$ million in 2009 and to \$6 805 million in 2010. In 2011, however, inward FDI in South Africa increased significantly as the value of greenfield FDI projects almost doubled to $\$ 12410$ million. Some of the circumstances that contributed to this turnaround could be the "continuing rise in commodity prices and a relatively positive economic outlook for subSaharan Africa" (UNCTAD, 2012:xvi). The implementation by South Africa of the new Companies Act is also regarded as a reason for increased FDI, as the changes positively affect the restructuring of corporate groups (UNCTAD, 2012:81). South Africa further ranked $14^{\text {th }}$ on the list of transnational corporations' top prospective host economies for 2012-2014. This list reveals the economies that transnational corporations selected as the most likely destinations for their FDI in the medium term (UNCTAD, 2012:22). This ranking for prospective host countries, together with the increase in FDI, could indicate that foreign investors have a favourable attitude towards South Africa and have confidence in the country's potential for growth.

Despite this improvement, the 2012 World Investment Report indicates that South Africa "received less FDI than could be expected 
based on economic determinants". This statement is based on South Africa's ranking on the United Nations Conference on Trade and Development (UNCTAD) FDI Attraction Index, which measures the success of economies in attracting FDI, compared to South Africa's ranking on the UNCTAD FDI Potential Index, which indicates an economy's potential to attract FDI (UNCTAD, 2012:xv, 32). The Organisation for Economic Cooperation and Development (OECD) (OECD, 2008a:560) also previously argued that South Africa should be attracting even higher levels of FDI than were achieved at the time. In 2008, the then Finance Minister, Trevor Manuel, acknowledged that South Africa required higher levels of foreign investment to grow the country's economy. He appealed to the South African business community to support government's attempt to "make this country an attractive destination for foreign investment" (National Treasury, 2008).

It is believed that South Africa has great potential to improve its FDI inflow and to receive benefits accruing from FDI. However, the country has several constraints that hinder FDI, such as skills shortages, exchange controls, crime, extensive labour legislation and low growth rates (Tuomi, 2009:37-39, 171; World Economic Forum, 2010:302). Before these problems can be addressed, an understanding of the key determinants that influence the investors' decision in choosing a host country for investment is necessary.

\subsection{Key determinants for attracting FDI}

When an investor decides to invest abroad, several factors influence the selection of a prospective host country. Each investment decision considers the unique circumstances and requirements of both the investor and the host country. Resource-seeking investors are interested in abundant natural resources, market-seeking investors look for large and expanding markets, and export-seeking investors pursue a competitive and efficient base for export production (Easson, 2004:27).

The 2003 World Investment Report (UNCTAD, 2003:85) and the OECD (2007:4) listed a number of host country determinants that influence FDI, such as economic, political and social stability, rules regarding entry and operations, market size, access to output markets, raw material, skilled labour, transport and communication costs, investment promotion, tax rates and investment incentives. Zanatta, Costa and Filippov (2006:6) add that the host country's bargaining power in attracting FDI is dependent on the assets that it is able to provide to investors, such as its market size, geographical location, human capital and infrastructure. Fedderke and Romm (2005:758) concluded that FDI is strongly affected by the net rate of return and the risk profile of FDI liabilities. They further argue that policy plays an important role in reducing political risk, moderating wages, ensuring property rights, bolstering growth in market size and lowering taxes.

Tuomi (2009:39, 63) also considered the variables and determinants that affect the investment climate of the host country and she added factors such as the absence of crime and corruption, basic and specialised infrastructure and the effectiveness and functionality of the financial sector. Tuomi (2009:117) went on to classify the determinants that affect the investors' choice of a host country into three groups, namely:

- Country endowments;

- The investment climate; and

- Incentives.

Country endowments refer to the beneficial elements and attributes of a country, such as natural resources, geographical location or a large population. The investment climate of a country is determined by, amongst others, its political and economic stability, the quality of labour and the availability of infrastructure. Incentives include, but are not limited to cash grants, tax exemptions and accelerated capital allowances.

Although Wilson's (1993) study of the characteristics that determine the location decisions for investment of prominent businesses is dated, it is interesting to observe the similarities between his categorisation and that of Tuomi. Wilson (1993:228) also classified the key investment determinants into three categories of considerations:

- Coupling considerations (activities that combine a firm's value chain), such as 
technology, transport costs and the need to be close to customers (markets);

- Country considerations (or country-specific factors), such as infrastructure, political stability, the labour force and financial systems; and

- Coordination considerations, which are associated with incentives and tax planning.

It is clear that Wilson's categories of invest- ment considerations and Tuomi's categories of investment determinants are very similar. What is interesting, is that in both cases, incentives are mentioned separately as one of the three categories, which indicate their significance in the investment decision. To consider this further, Tuomi's categories of determinants that influence the investment decision are graphically illustrated in figure 1.

Figure 1

The investment decision: determinants influencing the choice of country

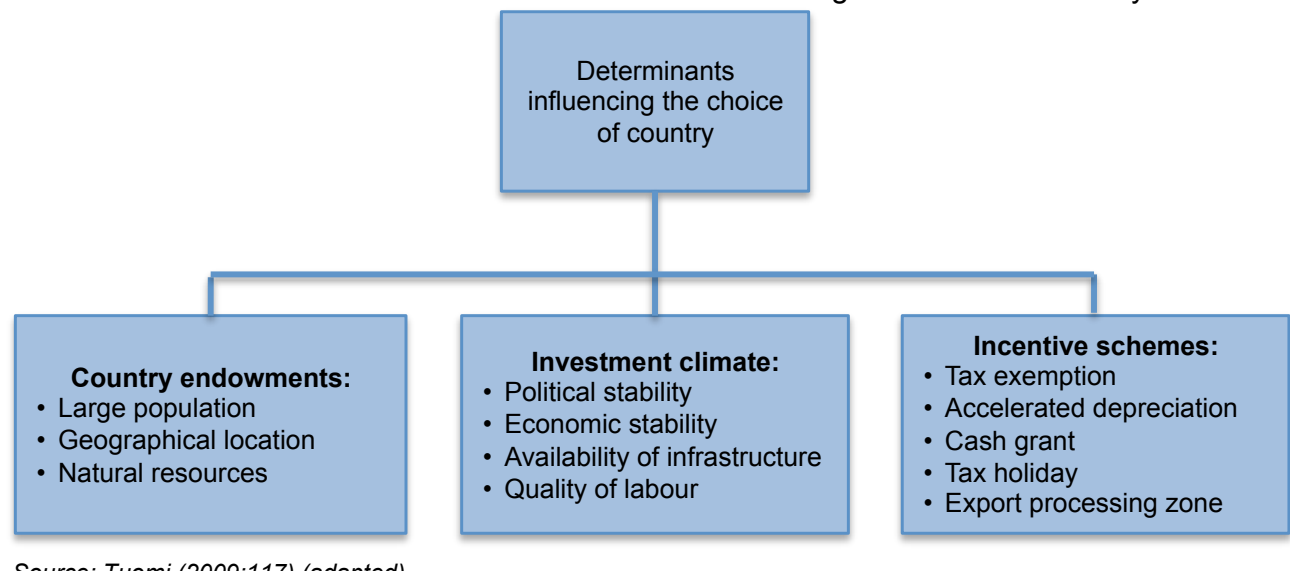

Source: Tuomi (2009:117) (adapted)

All three groups of determinants interact with one another and a change in one of them could affect the other determinants. The improvement of either of the first two groups, namely country endowments and investment climate, would require a long-term approach by a country's government. The reason for this is that a government might have no or little control over some of these factors, like the availability of natural resources, or the determinants are affected by a number of external factors, such as economic stability. This is why investment experts regard incentives as an important policy variable for improving a country's investment attractiveness for FDI (Lim, 2005:64). Incentives can be utilised by a host country to compensate for unavoidable investment obstacles (like political instability), to advertise the country as a desirable location for foreign investment and to encourage specific types of investments that generate particular benefits for the economy as a whole (Wentzel, 2010:38-40).

Although Kransdorff (2010:79) believes that FDI increases when the host country's investment fundamentals (such as political and economic stability) improve, he agrees that competitive incentives (specifically tax incentives) are necessary in the short-term to enhance FDI inflows and boost economic development. The OECD (2007:4-5) agrees that incentives may influence the location of FDI and that "tax incentives are much easier to provide than to correct deficiencies in, for example, infrastructure or skilled labour".

\subsection{Incentives as a short-term intervention to attract additional FDI}

Although incentives were historically found to play a marginal role in the investment decision of foreign investors (Moran, 1999:102), Kokko (2003:30-31) pointed out that this picture has changed during the past decade. Incentives have become an increasingly important determinant of international investment decisions due to globalisation, the increased flow of raw materials, as well as technological and 
communication innovations. Although incentives may be one of the last considerations in the investment decision, they appear to have an important role to play in finalising choice of location (Zanatta et al., 2006:4; Lim, 2005:63). MNE executives readily admit that the influence of incentives has increased and "econometric studies, which used to find little or no effect of incentives, now suggest that they have become more significant determinants of international direct investment flows" (Conference Board of Canada, 2004: 21). Morisset and Pirnia (2000:8) agree that tax policy affects the decisions of some investors some of the time. They noticed that FDI increased more than fivefold between 1985 and 1994 in tax haven countries, which clearly indicates the influence of tax (or the elimination thereof) on FDI decisions. The OECD (2008b:557) confirmed the influence of incentives when it observed that investors were discouraged to initiate long-term investments in South Africa during 2007, due to the possibility of the Motor Industry Development Programme incentive being discontinued. Kransdorff (2010:71-72) adds that tax incentives, specifically, have a very strong influence on attracting FDI when the fundamentals of several host countries are similar.

Incentives are valuable instruments which can assist in alleviating distortions in the host country's investment climate and to help attain its growth objectives. All Middle East and North African countries offer incentives to boost employment and to improve their competitive position in today's global economy (OECD, 2007:3). Incentives can compensate for market failures, are often regarded as effective policy tools for achieving economic and social objectives and are seen as easy to implement (OECD, 2007:3). Incentives may be a viable policy option when the host country faces high unemployment and weak growth. Targeted foreign incentives may also be warranted when the policies of the host country unfairly discriminate against foreigners (Tuomi, 2009:69-70). According to Kransdorff (2010: 75 ), a country's fiscal generosity could be signalled to foreign investors by the number and nature of fiscal incentives offered.

An argument that is often made in favour of incentives is that, in order to remain compe- titive, a country must offer incentives if its neighbours offer incentives (Moran 1999:103). This argument may especially have some force when the investment decision is strongly affected by taxes (Easson, 2004:12; OECD, 2007:7). Biggs (2007:4) argues that fiscal incentives and a greater reliance on a diversified tax base (including income tax, VAT and other taxes) can help to attract investment, encourage firms to expand supply and advance domestic production. Investors are focused on minimising operating costs and reduced taxes will therefore have a particularly strong effect on the investment decision (Kransdorff, 2010:71). The Conference Board of Canada (2004:21) found that "tax policies can have a significant effect on the volume and location of FDI", due to higher after-tax returns when tax incentives are utilised by investors.

Most countries have initiated some promotion and facilitation measures to attract and facilitate foreign investment. According to the 2012 World Investment Report (UNCTAD, 2012:109), these measures "often include the granting of fiscal or financial incentives, and the establishment of special economic zones". As at 2011, at least 44 countries had adopted 29 policy measures directed specifically at FDI. Twenty-one of these measures offered specific incentives to foreign investors, which directly or indirectly created an attractive environment for FDI (UNCTAD, 2012:76-77). According to Tuomi, one of the reasons for the widespread use of incentives is that governments regard incentives as necessary to compete with other countries as investment locations for foreign investors. Another reason is that the use of exchange rate intervention is restricted by World Trade Organisation rules, which increased the need for other instruments that signal which governments are dedicated to development (Tuomi, 2009: 27-28).

When the host country is able to negotiate favourable terms in achieving its growth objectives when providing incentives, the effectiveness of incentives increases (Zanatta et al., 2006:4). Some developing countries have utilised incentives effectively to encourage foreign investment. Malaysia has been offering incentives such as tax holidays of up to 10 years for foreign investments with pioneer 
status, a reinvestment allowance, an investment tax allowance, and special deductions for training for a while already (Nathan-MSI Group, 2004:3-3). UNCTAD recognised that this incentive policy was one of the primary influences in attracting foreign investment to Malaysia (UNCTAD, 2002:207). Costa Rica's incentive in the form of an export processing zone was one of the factors that convinced a large international company to choose Costa Rica as its investment destination in preference to several other countries (Nathan-MSI Group, 2004:3-3). In South Africa, as well, the Motor Industry Development Programme was a successful instrument for attracting FDI in the manufacturing sector (OECD, 2008c:77; Tuomi, 2009:166). Motor manufacturers in South Africa even warned that South Africa's motor industry (which contributes significantly towards job creation) would not be viable without incentives (Cocayne, 2007:4).

Singapore's government provides several competitive direct and indirect incentives for FDI in key sectors. UNCTAD found that strong institutions, plentiful infrastructure and generous investment incentives, as mentioned above, are the main contributors to Singapore's positive FDI climate (UNCTAD, 2011:39). Tax incentives persuaded Foxconn (the world's largest manufacturer of electronic components and the largest exporter in Greater China) to build five additional factories in Brazil to cater to the growing demand for Apple iPads and other tablets, and this expansion is expected to produce 400 million units annually (UNCTAD, 2012:55). The 2012 FDI Report also recognised that continuous large-scale government tax incentives and subsidies have encouraged rapid growth in the global renewable energy sector (McMillan, Ewing, McReynolds, et al., 2012: 15). Based on all these examples of countries that successfully implemented incentive policies, it is evident that incentives have a positive effect on FDI and growth.

Due to the fact that South Africa possesses positive locational factors (such as a wellsituated geographical location and six deep-sea harbours), Cleeve (2008:11) argues that fiscal incentives could significantly influence FDI inflows to the country, especially if investment is efficiency-seeking or strategic-asset-seeking. Furthermore, the manufacturing sector in
South Africa has been identified by the United Nations Industrial Development Organisation (UNIDO) as particularly important for growth since it has the highest growth multipliers (UNIDO 2012b:10). To attract increased investment to the South African manufacturing industry, additional incentives may have to be introduced. By studying incentive measures that are provided by other countries, recommendations can be made for the initiation of further incentives.

\section{3}

\section{Selection of countries and research methodology}

A comparative study was done between the incentives available in South Africa and those available in two foreign countries. This research focused specifically on incentives for manufacturing enterprises and the selection method used in determining the foreign countries therefore made use of information that would ensure the comparability of their manufacturing sectors. The selection of the two countries was based on three criteria, namely performance of the manufacturing sector of each country with reference to manufacturing value added, gross domestic product (GDP) per capita and geographical location.

The data for the amount of value added (in US dollars) by the manufacturing sector of most countries in 2009 (the most recent information available at the time the countries were selected) was obtained from the 2011 World Development Indicators report (World Bank, 2011:202). According to this report, South Africa's amount for manufacturing value added during 2009 was the equivalent of \$39 014 million. Countries with manufacturing value added values ranging from $\$ 6$ million below to $\$ 12$ million above South Africa's value added amount were identified. Seven countries, namely the Czech Republic, Denmark, Finland, Ireland, Malaysia, Saudi Arabia and Singapore, met these criteria. Due to the fact that this study compares South Africa to only two foreign countries, some of the seven countries needed to be eliminated from the selection options. For this reason the GDP per capita at nominal values of these countries was 
also taken into account for selection purposes. This indicator reveals the comparability of the countries' economies (Kaul \& TomaselliMoschovitis, 2009). The GDP per capita of countries in 2009 was obtained from the International Monetary Fund (2009). Of the seven countries mentioned earlier, only Malaysia's GDP per capita (\$7 469) was similar to that of South Africa (\$5 635). The other six countries' GDP per capita range between $\$ 14871$ and $\$ 55942$, as they have more advanced economies. It follows that South Africa could be compared to Malaysia, as both these countries have a similar level of economic development and manufacturing value added.

It would be useful to compare the incentives offered by South Africa to those offered by a government with a more advanced economy, as this could assist in gaining an understanding of what South Africa's approach should be for future growth. Singapore was therefore also selected because of its proximity to Malaysia. The fact that Malaysia and Singapore's economies are primarily dependent on manufacturing (Encyclopaedia of the Nations, 2010) and both these countries are situated in the same geographical region of Southeast Asia were regarded as providing sufficient reasons for comparing them to South Africa. It is possible that potential bias may occur because of the close geographical location of Malaysia and Singapore as the potential competition for FDI between these two countries might lead to them offering similar and more favourable investment incentives than South Africa.

The study made use of a literature review. This involved the collection, analysis and interpretation of relevant published information. The information was obtained from books, articles (both secondary sources) and legislation (primary sources) (such as South Africa's Income Tax Act, Malaysia's Income Tax Act, Malaysia's Promotion of Investment Act, Singapore's Income Tax Act and Singapore's Economic Expansion Incentives Act). Information was also obtained from electronic sources in accessing the official websites of government entities (such as the South African Department of Trade and Industry, the Inland Revenue Board of Malaysia, the Malaysian Industrial Development Authority and the Inland Revenue Authority of Singapore).

\section{4}

\section{Analysis and findings}

The similarities and differences between the incentives offered by South Africa and those offered by Malaysia and Singapore are explained below. Prescott (1991:17) warns that a comparison between countries in respect of the specific features of their tax system should be done with caution, due to the fact that the tax systems of countries generally differ significantly. Comparison of specific features should ideally take into account the general system of which they are part. However, valuable information, as discussed later, can still be obtained from a comparison between only the incentives (excluding the tax systems) applicable to the manufacturing industry offered by South Africa, Malaysia and Singapore.

There are numerous types of incentives, each with unique features. For comparison purposes, this research study classify incentives into three main categories, namely incentives that promote specific investment (incentives encourage and facilitate the incorporation of new manufacturing companies and the expansion of existing ones in specific industries or geographical areas that will benefit the country's economy), incentives that encourage investment in capital assets (defined after figure 2) and incentives that reduce the company's fiscal burden (defined after figure 2).

Incentives that are currently available for the manufacturing sector in South Africa (either specifically or as part of incentives generally available to all industries) are summarised in figure 2 under the three main categories of incentives listed above.

This article reports only on incentives that encourage investment in capital assets (in other words capital allowances that serve as a tax relief designed to allow the cost of certain of the investors' assets to be written off against their taxable income) and incentives that reduce the investors' fiscal burden (in other words tax relief designed to allow investors to deduct certain expenses from their income, or to apply a lower tax rate to their taxable income, thereby reducing their tax liability). Table 1 lists these incentives offered by all three countries and shows similar types of incentives offered by more than one country, 
as well as unique incentives offered by only one of them. The sources (literature references) of these incentives are provided in the detailed discussion of each incentive below table 1 .

\section{Figure 2}

Incentives available to manufacturers in South Africa

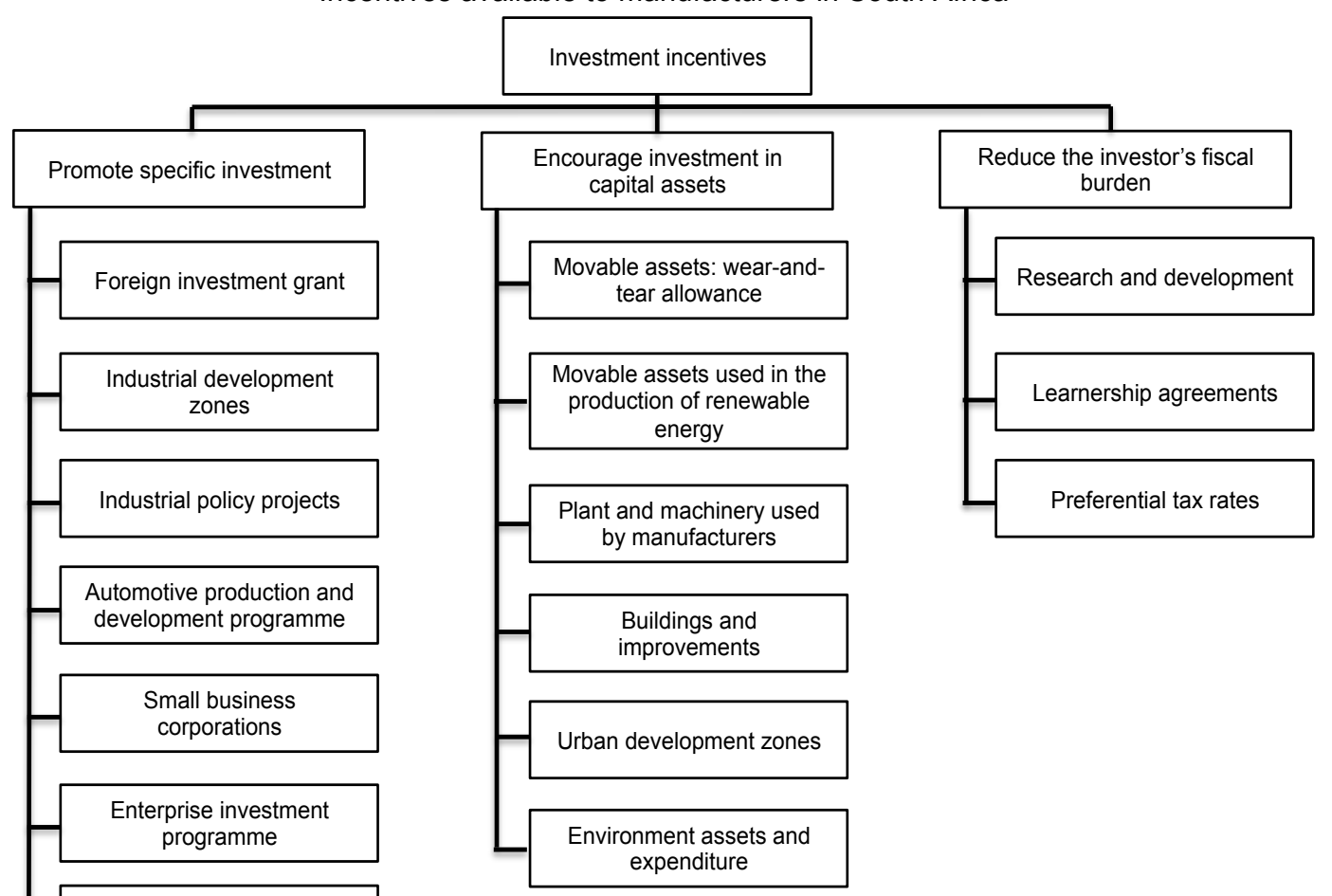

Support programme for industrial innovation

Source: Wentzel (2010:95) (adapted)

Table 1

Comparison of manufacturing incentives offered by South Africa, Malaysia and Singapore to encourage investment in capital assets and reduce investors' fiscal burden

\begin{tabular}{|c|c|c|c|}
\hline Type of incentive & South Africa & Malaysia & Singapore \\
\hline \multicolumn{4}{|c|}{ Encourage investment in capital assets } \\
\hline $\begin{array}{l}\text { Non-manufacturing assets: } \\
\text { wear-and-tear allowance }\end{array}$ & $\begin{array}{l}\text { Several generators }-6.67 \% \\
\text { for } 15 \text { years }\end{array}$ & $\begin{array}{l}\text { Several generators - year } 1 \text { : } \\
60 \% \text {, year } 2: 40 \%\end{array}$ & Several generators - $100 \%$ \\
\hline $\begin{array}{l}\text { Plant and machinery used } \\
\text { by manufacturers - general }\end{array}$ & $\begin{array}{l}\text { After } 1 \text { March 2002: year } 1- \\
40 \% \text {, years } 2,3, \& 4-20 \%\end{array}$ & $\begin{array}{l}\text { Heavy machinery and } \\
\text { vehicles: year } 1-40 \% \text {, years } \\
2-4 \text { - } 20 \% \\
\text { Plant and equipment: year } 1 \text { - } \\
34 \% \text {, years } 2-6 \text { - } 14 \% \\
\text { Accelerated: } \\
\text { - Expand after } 15 \text { year ITA: } \\
\text { year } 1 \text { - } 60 \% \text {, years } 2 \& 3 \text { - } \\
20 \%\end{array}$ & $\begin{array}{l}\text { Initial }=20 \% \\
\text { Annual = remaining cost } \\
\text { claimed over } 5 \text { to } 16 \text { years } \\
\text { Accelerated: } \\
\text { - Acquired during } 2010 \text { and } \\
2011 \text { : year } 1=75 \% \text {, year } 2 \\
=25 \%\end{array}$ \\
\hline $\begin{array}{l}\text { Industrial buildings and } \\
\text { improvements }\end{array}$ & $\begin{array}{l}\text { - Industrial building: } 5 \% \text { for } \\
20 \text { years } \\
\text { - Commercial building: } 5 \% \text { for } \\
20 \text { years }\end{array}$ & Year $1-13 \%$, years $2-30-3 \%$ & $\begin{array}{l}\text { Initial }=25 \% \\
\text { Annual }=3 \%\end{array}$ \\
\hline
\end{tabular}




\begin{tabular}{|c|c|c|c|}
\hline Type of incentive & South Africa & Malaysia & Singapore \\
\hline Environmental expenditure & $\begin{array}{l}\text { - Environmental treatment } \\
\text { and recycling assets - year } \\
1-40 \% \text {, years } 2,3 \& 4 \text { - } \\
20 \% \\
\text { - Environmental waste } \\
\text { disposal assets - } 5 \% \\
\text { - Environmental remediation } \\
\text { and restoration costs - } \\
100 \%\end{array}$ & $\begin{array}{l}\text { Environmental protection } \\
\text { equipment: year } 1-60 \% \text {, } \\
\text { years } 2 \& 3-20 \%\end{array}$ & $\begin{array}{l}\text { - Funding for } 80 \% \text { of costs for } \\
\text { waste reduction and } \\
\text { recycling (applications } \\
\text { closed on } 28 / 9 / 12) \\
\text { - Energy-saving equipment: } \\
100 \%\end{array}$ \\
\hline $\begin{array}{l}\text { Renovation of business } \\
\text { premises and infrastructure }\end{array}$ & $\begin{array}{l}\text { - Refurbishment designated } \\
\text { zone }=20 \% \text { for } 5 \text { years } \\
\text { Construction in designated } \\
\text { zone }=\text { year } 1-20 \% \text {, years } \\
2-11-8 \%\end{array}$ & $\begin{array}{l}\text { - Renovations between } \\
10 \text { March } 2009 \text { and } \\
31 \text { December } 2010 \text { : years } \\
\text { 1\& } 2-50 \% \\
\text { - Infrastructure in promoted } \\
\text { area: } 100 \%\end{array}$ & $\begin{array}{l}\text { - Renovations between } \\
16 \text { February } 2008 \text { and } \\
15 \text { February } 2013: 33.3 \% \text { for } \\
3 \text { years } \\
\text { - } 2010 \text { \& } 2011-100 \%\end{array}$ \\
\hline $\begin{array}{l}\text { Movable assets used in the } \\
\text { production of renewable } \\
\text { energy }\end{array}$ & $\begin{array}{l}\text { Year } 1-50 \% \\
\text { Year } 2-30 \% \\
\text { Year } 3-20 \%\end{array}$ & $100 \%$ ITA for 5 years & No similar allowance available \\
\hline \multicolumn{4}{|c|}{ Reduce the investors' fiscal burden } \\
\hline $\begin{array}{l}\text { Research and } \\
\text { development }\end{array}$ & $\begin{array}{l}\text { - Qualifying operating } \\
\text { expenses - } 150 \% \\
\text { - Capital expenses - year } 1 \text { - } \\
40 \% \text { years } 2-4-20 \%\end{array}$ & $\begin{array}{l}\text { - Revenue costs: } 200 \% \\
\text { - Capital expenditure: } 50 \% \text { of } \\
\text { costs incurred within } 10 \\
\text { years }\end{array}$ & $\begin{array}{l}\text { - Staff cost and consumables } \\
=150 \%-400 \% \\
\text { - Expenses for research on } \\
\text { specific items = } 200 \% \\
\text { - Start-up companies: cash } \\
\text { grant of } \$ \$ 20250 \text { for } 3 \\
\text { years and surrender tax loss } \\
\text { - Partial grant: equipment, } \\
\text { training and professional } \\
\text { services costs for new } \\
\text { research }\end{array}$ \\
\hline Preferential tax rates & $\begin{array}{l}\text { - Corporate tax rate }=28 \% \\
\text { - Small business corporations: } \\
\text { - First R63 } 556=0 \% \\
\text { R63 } 557-\mathrm{R} 350000=7 \% \text {, } \\
\text { above R350 } 000=28 \% \\
\text { - Turnover }<\mathrm{R} 1 \mathrm{~m}=0-6 \% \text { on } \\
\text { turnover only }\end{array}$ & $\begin{array}{l}\text { - Corporate tax rate }=25 \% \\
\text { - Small-scale companies: } 20 \% \\
\text { on the first RM500 } 000 \text { of } \\
\text { chargeable income, } 25 \% \\
\text { income exceeding } \\
\text { RM500 } 000\end{array}$ & $\begin{array}{l}\text { Corporate tax rate }=17 \% \text { and } \\
\text { partial exemption of } \\
\text { chargeable income: } \\
-75 \% \text { of the first } \$ \$ 10000 ; \\
\text { and } \\
-50 \% \text { of the next } \$ \$ 290000\end{array}$ \\
\hline $\begin{array}{l}\text { Training expenses and } \\
\text { learnership agreements }\end{array}$ & $\begin{array}{l}\text { Commence agreement - } \\
\text { R30 000/R50 } 000 \text { per } \\
\text { employee } \\
\text { Complete training - R30 } 000 \\
\text { per employee or R30 } 000 \text { per } \\
\text { employee per year of } \\
\text { agreement }(>24 \mathrm{~m})\end{array}$ & $200 \%$ or financial assistance & No similar allowance available \\
\hline $\begin{array}{l}\text { Approved foreign loan } \\
\text { incentive }\end{array}$ & No similar allowance available & No similar allowance available & $\begin{array}{l}\text { Full/partial exemption on } \\
\text { withholding tax for interest } \\
\text { payments to non-residents }\end{array}$ \\
\hline Approved royalty incentive & No similar allowance available & No similar allowance available & $\begin{array}{l}\text { Full/partial exemption on } \\
\text { withholding tax for royalties or } \\
\text { technical assistance fees paid } \\
\text { to non-residents }\end{array}$ \\
\hline
\end{tabular}

The comparison reveals that there are several incentives that are similar for the three countries, but with closer scrutiny it becomes clear that in most instances the benefits that the manufacturing companies receive from the incentives differ. The discussion of the results from the comparison between these incentives considers only the benefit offered to the manufacturer, and does not examine any other requirements that need to be met in order to make use of these incentives or the limitations that apply. The similarities and differences between the incentives offered by the three countries are discussed in further detail in the next two sections.

\subsection{Incentives that encourage investment in capital assets}

South Africa, Malaysia and Singapore have a total of five incentives in common, which are 
discussed first. The one incentive that is provided only by South Africa and Malaysia is discussed thereafter.

\subsubsection{Non-manufacturing assets}

For the comparison of non-manufacturing assets, a generator was selected, as this asset is significant in ensuring continued manufacturing operation in the event of power failures. The deduction allowed by South Africa in respect of generators, is limited since only a small portion of the acquisition cost (6.67 per cent) is claimable by the investor every year (South Africa, 1962:sec 11(e); South African Revenue Service, 2011). This does not compare favourably with the rates allowed in Malaysia and Singapore where the full acquisition cost is deductible within two years or less (Malaysian Industrial Development Authority, 2012a: [10]); Singapore, 1947:sec 19A(3)). It is obvious that uninterrupted manufacturing operations are necessary for the industry to be profitable and in the light of the possible lack of electricity supply by the South African Electricity Supply Commission (ESCOM) (Department of Minerals and Energy, 2008), generators are essential equipment for the South African manufacturing sector.

To align South Africa's wear-and-tear allowance rate with those of Malaysia and Singapore, the South African government could consider allowing the deduction of the full acquisition cost of generators over two years, either equally with 50 per cent each year, or 60 per cent in the year of acquisition and 40 per cent in the subsequent year, as is currently offered in Malaysia.

\subsubsection{Manufacturing plant and machinery}

A comparison of the deductions available in respect of manufacturing plant and machinery reveals that South African companies are allowed to claim the cost of manufacturing plant and machinery over a shorter period (four years) (South Africa 1962:sec 12C) than the other two countries (between 4 and 16 years) (Inland Revenue Board of Malaysia, 2012a; Singapore, 1947:sec 19). However, both Malaysia and Singapore offer, in addition, an accelerated allowance on new plant and machinery acquired during or after a specific time frame (Malaysian Industrial Development Authority, 2012a:[10]; Singapore, 1947:sec
19A(1B)). This enables manufacturing companies to claim the cost of these assets over a period of two to three years, which appears to be more beneficial than the allowance offered by South Africa (claimable over four years).

Manufacturers in Malaysia and Singapore would be more inclined to acquire new plant and machinery during the specific time frame than a manufacturer in South Africa. However, South Africa has been offering its allowance over a longer period (since 1 March 2002), and manufacturers are encouraged to purchase new plant and machinery at any given time and not only within a specific time frame. This would probably persuade South African manufacturers to invest in new plant and machinery more often, which could result in a more productive manufacturing industry. No further recommendations are thus offered in order to enhance this incentive.

\subsubsection{Industrial buildings}

South Africa's annual allowance rate for industrial buildings of 5 per cent (South Africa, 1962:sec 13) is higher than the 3 per cent rate permitted by Malaysia (Malaysian Industrial Development Authority, 2012b:[1]) and Singapore (Singapore, 1947:sec 16). However, a significant advantage is created for investors in industrial buildings in both Malaysia and Singapore since these regimes make provision for an initial allowance in the year of acquisition. Malaysia offers an initial allowance of 10 per cent (Malaysian Industrial Development Authority, 2012b:[1]), while Singapore offers one of 25 per cent (Singapore, 1947:sec 16). This incentive, which is essentially an increased deduction in the year of acquisition, may encourage a manufacturing company to invest in industrial buildings and improvements, due to the fact that the immediate benefit of a tax deduction of a greater portion of the capital expenditure compensates for the large initial capital outlay (deposit and transfer duty) in the year of acquisition. In this way the capital expenditure and the major benefit of the investment incentive are linked to each other in the same year of assessment, which would provide relief from a cash flow perspective.

The South African government could 
consider revising the industrial buildings and improvements incentive in order to allow a significant initial allowance in the year of acquisition, together with an annual allowance thereafter. If the example of Malaysia, another developing country, is followed, then an initial allowance of between 10 per cent and 15 per cent should result in a comparable advantage to South African investors in industrial buildings. Accordingly, the annual allowance simultaneously could be reduced from 5 per cent to 3 per cent.

\subsubsection{Environmental assets}

The environmental protection asset incentives offered by the three countries are very different. South Africa's allowance is claimed over a longer period (four years) (South Africa, $1962: \mathrm{sec}$ 37B) than that of Malaysia (three years) (Ministry of Finance Malaysia, 2012a), but in addition, South Africa allows a remediation and restoration deduction (South Africa, 1962:sec 37B) which Malaysia and Singapore do not offer. Singapore's incentive design is different from South Africa and Malaysia, as it allows a full deduction for energy-saving equipment (Singapore, 1947:sec 19A(6)) and provides a cash grant to reimburse most of the capital cost incurred by a manufacturer with regard to recycling and waste reduction (National Environment Agency, 2012).

It is clear that the design of the current South African environmental incentives was carefully considered, as three different types of environmental expenditure are deductible. In the future, the South African government could consider Singapore's incentives relating to environmental protection should the need arise to encourage this type of expenditure even more. However, there seems no need to adjust these incentives currently offered by South Africa.

\subsubsection{Refurbishment or renovation of buildings}

All three countries offer a capital allowance for the renovation of commercial business premises (in South Africa's case, only in a specified area called a designated zone), although the rates offered by Malaysia (50 per cent) (Malaysia, 1967:schedule $3 \mathrm{sec} 32 \mathrm{~A}(1)$ ) and Singapore (33.33 per cent or 100 per cent depending on the date of purchase) (Singapore, 1947:sec $14 \mathrm{Q}(3 \mathrm{~A})$ ) are more generous than those provided by South Africa (20 per cent) (South Africa, 1962:sec 13quat). Both South Africa and Malaysia also offer a capital allowance in respect of the construction of commercial buildings and infrastructure in a specified area (designated zone), and again it is evident that these capital costs may be deducted over a shorter period in Malaysia (1 year) (Malaysia, 1986:sec 4) than in South Africa (11 years) (South Africa, 1962:sec 13quat). However, manufacturers focus on manufacturing activities and assets, therefore commercial buildings and buildings in designated zones should not form a significant part of a manufacturer's expenses. No recommendations are currently made to increase the deduction rates allowed by South Africa.

\subsubsection{Renewable resources to generate energy}

Malaysian manufacturing companies that incur capital costs in acquiring equipment that uses renewable resources to generate energy, may claim a 100 per cent investment tax allowance within a five-year period (Malaysian Industrial Development Authority, 2012c), while South African companies may claim these capital costs over three years, with a 50 per cent allowance in year 1 , a 30 per cent allowance in year 2 and 20 per cent allowance in year 3 (South Africa, 1962:sec 12B). It is evident that Malaysia provides a more beneficial incentive than South Africa. However, due to the fact that half of the capital costs incurred by a South African company may be claimed in the year of acquisition, a significant deduction is allowed initially. The remaining amount is then deductible over the next two years, which is not an extensive period. Since the rising capacity shortage in electricity in South Africa and the corresponding rising cost thereof is considered to pose a serious challenge not only to the manufacturing industry (UNIDO 2012: 16 ), but to the economy as a whole in achieving a targeted 6 per cent GDP growth rate (UNIDO 2012:114), measures to further promote the production of renewable energy in South Africa should be considered. In this regard an accelerated allowance of 100 per cent of the capital costs could be considered. 


\subsection{Incentives that reduce the investor's fiscal burden}

The two incentives that South Africa, Malaysia and Singapore have in common are discussed first, followed by the one incentive that only South Africa and Malaysia have in common and the two incentives provided only by Singapore.

\subsubsection{Research and development}

The comparison between South Africa, Malaysia and Singapore reveals that the research and development incentives of the three countries have various features and rates in common. All three countries provide a research and development incentive which allows the deduction of operating expenses in excess of the actual expense (South Africa, 1962:sec 11D; Malaysia, 1967:sec 34A(4); Singapore, 1947:sec 14DA), while only South Africa and Malaysia offer a deduction for capital expenses incurred for research and development purposes (South Africa, 1962:sec 11D; Malaysian Industrial Development Authority, 2009:42).

Although Singapore does not specifically provide for a deduction of capital expenditure, it does offer a wide range of other incentives to encourage new and specific forms of research and development, namely: a 200 per cent deduction of specific expenses such as computer software (Singapore, 1947:sec 14E); a cash grant for start-up companies that incur extensive research and development expenses in developing a product (Singapore, 1947:sec $37 \mathrm{H}$ ); and a partial grant for equipment, training and professional services incurred for new research (Singapore Economic Development Board, 2012). The South African government could consider introducing these incentives if it becomes necessary to further encourage research and development, for example improved manufacturing methods or advanced products.

\subsubsection{Corporate tax rates}

The corporate tax rates of South Africa (28 per cent) (Accountancy SA, 2012:4) and Malaysia (25 per cent) (Inland Revenue Board of Malaysia, 2012b) are comparable; however, a tax rate that is 3 per cent lower could have a significant impact on a company with high taxable income. Both South Africa and Malaysia also offer special corporate tax rates to small business enterprises (Accountancy SA, 2012:7; Inland Revenue Board of Malaysia, 2012b). Singapore's corporate tax rate is significantly lower than the tax rates applied in South Africa and Malaysia, and it is evident that the low tax rate of 17 per cent, together with the partial exemption of income (Inland Revenue Authority of Singapore, 2012), is a significant incentive to any profitable manufacturing company. It should be noted, however, that Singapore is an advanced economy, which could contribute substantially to the fact that this country is able to charge a significantly low corporate tax rate. It is assumed that an incentive like this would thus not be ideal for a developing country like South Africa, since the country relies heavily on its tax revenue from companies (which constitutes 20.4 per cent of taxes on income and profits) (National Treasury, 2012:20). Although South Africa decreased its corporate tax rate from 35 per cent to 30 per cent in 1999 , then to 29 per cent in 2005, and again to 28 per cent in 2008 (Accountancy SA, 2012:4), a further reduction in the corporate tax rate may be required to ensure the country's comparability to other countries such as Malaysia in order to effectively compete with these destinations as an investment destination.

It is acknowledged that several factors would influence a decision like this. Furthermore, opposition parties (Marais, 2009) have appealed to the government to lower the corporate tax rate and it is expected that serious consideration is annually given to this aspect by the Minister of Finance. It may perhaps be argued that, if it were possible and beneficial for all parties involved, government would have decreased the corporate tax rate since 2008, but they have not done so. Therefore, no further recommendation is made to lower the corporate tax rate with immediate effect.

\subsubsection{Employee training}

Malaysia allows a double deduction of training expenditure incurred (Ministry of Finance Malaysia, 2012b). However, the South African government allows additional deductions (of R30 000 or R50 000 per employee for every year that the employee is part of a learnership agreement, as well as when the agreement is 
successfully completed) to the single deduction of training expenses (South Africa, 1962:sec $12 \mathrm{H})$. These two incentives could therefore provide a comparable benefit to companies in South Africa and Malaysia, depending on the amount of training expenses incurred by them. Although the deduction of additional training costs over and above the actual expense incurred is capped in terms of the South African tax rules, the mere fact that an additional deduction is granted is a positive consideration for investors that plan to invest substantial amounts into staff training. Therefore no recommendation is made about revising the learnership agreement incentive offered by South Africa.

\subsubsection{Royalties and interest payments to non-residents}

Singapore offers full or partial exemption on withholding tax relating to interest paid on loans obtained to acquire productive equipment (Singapore, 1967:sec 59), and on technical assistance fees paid by a manufacturing company to its non-resident holding company (Singapore, 1967:sec 64). This reduction in business costs encourages foreign direct investment and the transfer of foreign technology and know-how to the host country. This may be an attractive incentive for South Africa to consider in order to increase foreign direct investment and to obtain foreign expertise and skills transfer in the economy. The South African government could consider introducing a new incentive relating to royalties and interest payments to nonresidents, in order to achieve its aim of increasing foreign direct investment. The proposed benefit to the investor is a full exemption of withholding tax on interest payments and royalties or technical fees payable to non-residents.

The above analysis clearly indicates that there is some scope for South Africa to introduce additional incentives and amend existing incentives in order to remain competitive in the pursuit for increased FDI. It is however paramount from a policy perspective, that in designing FDI-attraction policies, policy-makers in developing countries should consider not only the short-run costs and benefits of FDI, but also their medium to long- term dynamic consequences (UNIDO, 2012a:19). Furthermore, when designing incentives, the United Nations Industrial Development Organisation (UNIDO) emphasises that it is fundamental to the host country to focus scarce resources aimed at attracting FDI towards firms that are more likely to produce large spill overs and linkages in the local economy (UNIDO, 2012a:1).

\section{5}

\section{Conclusion}

Foreign direct investment (FDI) is important for facilitating the growth of a country's economy. Several authors agree that South Africa needs to increase its inward FDI. The aim of this article was to explore which intervention measure could be launched to enhance the country's attractiveness for foreign investors.

The literature review demonstrated that there are several key determinants that influence foreign investors' decisions in the choice of an investment country. Incentives are, however, the only determinant that can be employed by a country's government as a short-term intervention for attracting additional FDI. Incentives can be utilised by a host country to compensate for unavoidable investment obstacles (like political instability), to advertise the country as a desirable location for foreign investment and to encourage specific types of investments that generate particular benefits for the economy as a whole.

In order to identify additional incentives that the South African government could introduce or existing incentives that could be amended, a comparative study was done. The comparison provided insight into the incentives that are currently offered in the manufacturing sectors of South Africa, Malaysia and Singapore. The research was focused on incentives that encourage investment in capital assets. Incentives that reduce the investor's fiscal burden were also considered.

The findings from the comparative study show that Malaysia and Singapore offer some incentives that South Africa does not. All three countries also have several incentives in common, although an analysis of these incentives revealed that the design and benefits 
of these incentives for manufacturers differ in most cases. The results from the analysis of the comparison suggest that incentives relating to the following be considered for introduction or modification in South Africa:

Incentives that encourage investment in capital assets:

- Amend the current wear-and-tear allowance rate for generators to allow the deduction of the full cost over two years, either equally with 50 per cent each year, or 60 per cent in the year of acquisition and 40 per cent in the subsequent year, which is the permissible rate in Malaysia (par 4.1.1).

- Amend the current allowable deduction rate for industrial buildings by introducing an initial allowance of between 10 per cent and 15 per cent and reducing the annual allowance from 5 per cent to 3 per cent (par 4.1.3).

- Amend the current capital allowance on equipment used to produce renewable energy by providing an accelerated allowance of 100 per cent of the capital cost incurred (par 4.1.4).

Incentives that reduce the investors' fiscal burden:

- Introduce additional incentives to encourage research and development even further by providing a double deduction of expenses relating to research performed on specific items, a cash grant to start-up companies conducting research to develop a product, and a partial grant for equipment, training and professional services incurred in respect of new research (par 4.2.1).

- Introduce an incentive to encourage foreign direct investment in the manufacturing sector and the transfer of foreign technology and know-how by providing a full exemption of withholding tax on interest payments and royalties or technical fees payable to non-residents (par 4.2.4).

The research that this article reports on contributes to identifying a short-term intervention that could assist in the much-needed increase in FDI and ultimately in South Africa's economic development. It is acknowledged that the South African government cannot merely introduce incentives without careful consideration of all aspects involved and their impact on the economy. In order to achieve the desired outcome, the unique design and objective of each incentive should also be carefully considered. Addressing this shortterm intervention to attract additional FDI is essential for the country's economic growth and success.

\section{References}

ACCOUNTANCY SA, 2012. Tax guide 2012/2013. [n.p]: FHPKF Publishers.

ASAFO-ADJEI, A. 2007. Foreign direct investment and its importance to the economy of South Africa. MCom thesis, University of South Africa, Pretoria.

BIGGS, P. 2007. Tax Incentives to attract FDI. United Nations Conference on Trade and Development: FDI, Technology and Competitiveness. Proceedings of the Expert Meeting, 8-9 March, Geneva.

CLEEVE, E. 2008. How effective are fiscal incentives to attract FDI to sub-Saharan Africa. The Journal of Developing Areas, 42(1):135-153.

COKAYNE, R. 2007. Toyota sketches grim future without MIDP. Business Report, 5 October:4.

CONFERENCE BOARD OF CANADA. 2004. Foreign direct investment - decisions, determinants, and the role of taxation - a survey. Canada. Available at: http://www.conferenceboard.ca/elibrary/abstract.aspx?did $=646$ [accessed 2012-07-01].

DEPARTMENT OF MINERALS AND ENERGY. 2008. National response to South Africa's electricity shortage. Available at: http://www.info.gov.za/otherdocs/2008/nationalresponse_sa_electricity1.pdf [accessed 2010-06-28].

EASSON, A. 2004. Tax incentives for foreign direct investment. The Hague: Kluwer Law International. ENCYCLOPAEDIA OF THE NATIONS, 2010. Malaysia: manufacturing. Available at: http://www.nationsencyclopedia.com/economies/Asia-and-the-Pacific/Malaysia.html [accessed 2010-11-18]. FEDDERKE, J. \& ROMM, A.T. 2005. Growth impact and determinants of foreign direct investment into South Africa, 1956-2003. Economic Modelling, 23:738-760. 
HAZELHURST, E. 2011. State is not doing enough on FDI - Gordhan. Business Report, 15 March:2. HIGON, D.A. \& VASILAKOS, N., 2011. Foreign direct investment spillovers: evidence from the British retail sector. The World Economy:642-666.

INLAND REVENUE AUTHORITY OF SINGAPORE, 2012. Tax rates \& tax exemption schemes. Available at: http://www.iras.gov.sg/irasHome/page04.aspx?id=410 [accessed 2012-10-10].

INLAND REVENUE BOARD OF MALAYSIA, 2012a. Capital allowance: General. Available at: $\mathrm{http} / / /$ www.hasil.gov.my/goindex.php?kump=5\&skum=1\&posi=6\&unit=1\&sequ=1 [accessed 2012-06-02]. INLAND REVENUE BOARD OF MALAYSIA, 2012b. Tax rate of company. Available at: $\mathrm{http} / /$ www.hasil.gov.my/goindex.php?kump=5\&skum=2\&posi=5\&unit=1\&sequ=1 [accessed 2012-06-02]. INTERNATIONAL MONETARY FUND, 2009. Country composition of WEO groups. Available at: http://www.imf.org.external/pubs/ft/weo/2009/02/weodata/groups.htm [accessed 2012-03-11].

KAMATH, G.B. 2008. Impact of foreign direct investment in India. ICFAI University Journal of International Business, III(4). Mangalore, India: The Icfai University Press.

KAUL, C. \& TOMASELLI-MOSCHOVITIS, V. 2009. Statistical handbook on poverty in the developing world. Available at: http://books.google.co.za/books?id=B_gGbu9C8U8C\&printsec=frontcover\#v= onepage \&q\&f=false [accessed 2010-09-10].

KOKKO, A. 2003. Globalization and FDI policies. United Nations conference on trade and development: the development dimension of FDI: policy and rule-making perspectives. Proceedings of the Expert Meeting, 6- 8 November, Geneva.

KRANSDORFF, M. 2010. Tax incentives and foreign direct investment in South Africa. Consilience: The Journal of Sustainable Development, 3(1):68-84.

LIM, S. 2005. Foreign investment impact and incentives: a strategic approach to the relationship between the objectives of foreign investment policy and their promotion. Amsterdam: Elsevier

MALAYSIA, 1967. Income Tax Act, No 47 of 1967 as amended. Available at: http://www.scribd.com/doc/ 491820/Income-Tax-Act-1967 [accessed 2009-08-07].

MALAYSIA, 1986. Promotion of Investment Act, No. 327 of 1986. Available at: http://www.pytheas.net/ docs/malaysia/PromotionofInvestmentAct1986.pdf [accessed 2009-08-07].

MALAYSIAN INDUSTRIAL DEVELOPMENT AUTHORITY. 2009. Malaysia: Investment in the manufacturing sector - policies, incentives and facilities. Available at: http://www.mida.gov.my/env3/ uploads/Publications_pdf/MalaysiaInvestment_Policies_Icentives_Facilities/MIMSed0409(Eng).pdf [accessed 2012-06-02].

MALAYSIAN INDUSTRIAL DEVELOPMENT AUTHORITY. 2012a. Invest in Malaysia: incentives for investment. Available at: http://www.mida.gov.my/env3/index.php?page=manufacturing-sector-2 [accessed 2012-06-02].

MALAYSIAN INDUSTRIAL DEVELOPMENT AUTHORITY. 2012b. Incentives for investment: other incentives. Available at: http://www.mida.gov.my/env3/index.php?page=other-incentives [accessed 2012-0602].

MALAYSIAN INDUSTRIAL DEVELOPMENT AUTHORITY. 2012c. Invest in Malaysia: incentives for environmental management. Available at: http://www.mida.gov.my/env3/index.php?page=incentives-forenvironmental-management [accessed 2012-06-02].

MARAIS, K. 2009. No shortage of tips for Trevor Manuel. Business Report, 1 February:1.

MCMILLAN, C., EWING, G., MCREYNOLDS, R., MERVYN, J., MCLOUGHLIN, A. \& THOMPSON, M., 2012. The FDI report 2012 - global greenfield investment trends. London: The Financial Times Ltd. Available at: http://www.fdiintelligence.com/landing-pages/fdi-report-2012 [accessed 2012-08-08].

MINISTRY OF FINANCE MALAYSIA. 2012a. Accelerated capital allowance. Available at: www.treasury.gov.my/index.php?option $=$ com_content\&view $=$ article\&id=717\&Itemid $=200 \&$ lang $=$ en [accessed 2012-06-06].

MINISTRY OF FINANCE MALAYSIA. 2012b. Double deduction incentive. Available at: $\mathrm{http} / / /$ www.treasury.gov.my/index.php?option=com_content\&view=article\&id=706\&Itemid=200\&lang=en [accessed 2012-06-06].

MORAN, T.H. 1999. Foreign direct investment and development - The new policy agenda for developing countries and economies in transition. Washington: Institute for International Economics. Available at: 
http://books.google.co.za/books?id=2YZN1Bn9YwQC\&printsec=frontcover\&dq=moran+1998+foreign+dire $\mathrm{ct}+$ investment + and + development\&hl $=$ en\&sa $=X \&$ ei=VNU2UqmeLMeAhAec3IDQAg\&ved=0CDwQ6AEw $\mathrm{AA} \# \mathrm{v}=$ onepage $\& \mathrm{q}=$ moran $\% 201998 \% 20$ foreign $\% 20$ direct $\% 20$ investment $\% 20$ and $\% 20$ development $\& \mathrm{f}=$ false [accessed 2013-09-16].

MORISSET, J. \& PIRNIA, N. 2000. How tax policy and incentives affect foreign direct investment. Available from: <http://www.wds.worldbank.org/servlet/WDSContentServer/WDSP/IB/2001/01/20/ 000094946_01010905342188/Rendered/PDF/multi_page.pdf> [accessed: 2008-08-20].

NATHAN-MSI GROUP. 2004. Effectiveness and economic impact of tax incentives in the SADC region. [n.p.]:Nathan-MSI Group.

NATIONAL ENVIRONMENT AGENCY. 2012. Funds and incentives: 3R (Reduce, Reuse, Recycle) Fund. Available at: http://app2.nea.gov.sg/funds_3rfund.aspx [accessed 2012-10-30].

NATIONAL TREASURY. 2007. Economic policy and South Africa's growth strategy: speech on 19 March. South Africa: Department of National Treasury. Available at: http://www.treasury.gov.za/comm_media/ speeches/2007/2007031901.pdf [accessed 2012-08-03].

NATIONAL TREASURY. 2008. Speaking notes for first reading debate: 19 March. South Africa: Department of National Treasury. Available at: http://www.treasury.gov.za/comm_media/speeches/2008/ 2008031903.pdf [accessed 2010-08-03].

NATIONAL TREASURY. 2009. Budget speech: 11 February. South Africa: Department of National Treasury. Available at: http://www.treasury.gov.za/documents/national\%20budget/2009/speech/speech.pdf [accessed 2012-08-03].

NATIONAL TREASURY. 2011. A review framework for cross-border direct investment in South Africa. South Africa: Department of National Treasury. Available at: http://www.treasury.gov.za/documents/ national\%20budget $/ 2011 / \mathrm{A} \% 20$ review $\% 20$ framework $\% 20$ for $\% 20$ crossborder $\% 20$ direct $\% 20$ investment $\% 20 \mathrm{i}$ n\%20South\%20Africa.pdf [accessed 2012-08-27].

NATIONAL TREASURY. 2012. South Africa: Department of National Treasury. Available at: http://www.treasury.gov.za/publications/tax\%20statistics/2012/default.aspx [accessed 2012-10-23].

OECD (Organisation for Economic Cooperation and Development), 2007. Tax incentives for investment - A global perspective: experiences in MENA and non-MENA countries. Available at: http://www.oecd.org/ mena/investment/38758855.pdf [accessed 2012-07-04].

NATIONAL TREASURY. 2008a. OECD country study 2008: South Africa. Available at: http://www.oecd. org/southafrica/40573742.pdf [accessed 2009-08-03].

NATIONAL TREASURY. 2008b. Tax effect on foreign direct investment. Available at:

http://www.oecd.org/investment/investmentpolicy/40152903.pdf

[accessed 2011-03-12].

NATIONAL TREASURY. 2008c. OECD economic surveys: South Africa. Available at: http://www.oecd. org/eco/economicassessmentofsouthafrica2008.htm [accessed 2010-08-03].

PRESCOTT, M. 1991. The need for tax incentives. London: BFI Publishing.

SINGAPORE. 1947. Income Tax Act, Ordinance 39 of 1947 as amended. Available at: http://statutes.agc. gov.sg/aol/search/display/view.w3p;page=0; query=CompId\%3A7f942d8a-6814-408a-ad26-

45b4962b6a95;rec=0;resUrl=http\%3A\%2F\%2Fstatutes.agc.gov.sg\%2Faol\%2Fbrowse\%2FtitleResults.w3p\% 3Bletter\%3DI\%3Btype\%3DactsAll [accessed 2009-08-05].

SINGAPORE. 1967. Economic expansion incentives (relief from Income Tax) Act, No. 36 of 1967 as amended. Available at: http://statutes.agc.gov.sg/aol/search/display/view.w3p;page=0;query=CompId\% 3A3f514eb8-3ac2-49d7-95c8 4b5f96de7d5c;rec=0;resUrl=http\%3A\%2F\%2Fstatutes.agc.gov.sg\%2Faol\%2 Fbrowse\%2FtitleResults.w3p\%3Bletter\%3DE\%3BpNum\%3D1\%3Btype\%3DactsAll [accessed 2012-10-01]. SINGAPORE ECONOMIC DEVELOPMENT BOARD, 2012. Financial assistance and other incentive schemes. Available at: http://www.edbsingapore.jp/edb/sg/en_uk/index/why_singapore/Guide_to_Investing in_Singapore/financial_assistance.html [accessed 2012-07-13].

SOUTH AFRICA. 1962. Income Tax Act, No. 58 of 1962 as amended. Available at: http://www.acts.co.za [accessed 2012-03-05].

SOUTH AFRICAN REVENUE SERVICE. 2011. Binding general ruling (income tax): no. 7. Available at: http://www.sars.gov.za/home.asp?pid=4266 [accessed: 2012-08-03]. 
TUOMI, K.L. 2009. Fundamentals, tax incentives and foreign direct investment. $\mathrm{PhD}$ thesis, American University, Washington DC.

UNCTAD. (United Nations Conference on Trade and Development). 2002. World investment report 2002: transnational corporations and export competitiveness. New York: United Nations. Available at: http://unctad.org/en/docs/wir2002_en.pdf [accessed 2011-06-16].

UNCTAD. 2003. World investment report 2003 - FDI policies for development: national and international perspectives. New York: United Nations. Available at:

http://unctad.org/en/Docs/wir2003ch2_en.pdf [accessed 2012-08-22].

UNCTAD. 2011. How to create and benefit from FDI-SME linkages - Lessons from Malaysia and Singapore. New York: United Nations. Available at:

http://unctad.org/en/Docs/diaepcb200918_en.pdf [accessed 2012-08-22].

UNCTAD. 2012. World investment report 2012 - towards a new generation of investment policies. New York: United Nations. Available at: http://www.unctad-docs.org/files/UNCTAD-WIR2012-Overview-en.pdf [accessed 2012-08-22].

UNIDO (United Nations Industrial Development Organisation). 2012a. Which domestic firms benefit from FDI? Evidence from selected African countries. Available at:

http://www.unido.org/fileadmin/user_media/Publications/Research and_statistics/Branch_publications/Resea rch_and_Policy/Files/Working_Papers/2012/WP082012_Ebook.pdf [accessed 2013-09-15].

UNIDO. 2012b. Independent country evaluation Republic of South Africa. South Africa 2012. Available at: http://www.unido.org/fileadmin/user_media/About_UNIDO/Evaluation/Country_Reports/ebook\%20africa.pdf [accessed 2013-09-15].

UNIDO. 2013. FDI and local linkages in developing countries: Evidence from sub-Saharan Africa. Available at: http://www.unido.org/fileadmin/user_media/Publications/Research_and_statistics/Branch_ publications/Research_and_Policy/Files/Working_Papers/2012/WP072012_Ebook.pdff [accessed 201309-15].

WENTZEL, M.S.I. 2010. A comparative study of investment incentives available to the manufacturing sector in South Africa, Malaysia and Singapore. MCom thesis, University of South Africa, Pretoria.

WILSON, P.G. 1993. The role of taxes in location and sourcing decisions. In Alberto G., Glenn, H. \& Joel, S. (eds.) Studies in international taxation. Chicago: University of Chicago Press.

WORLD BANK. 2011. World development indicators 2011. Available at: http://issuu.com/world.bank. publications/docs/9780821387092_part2 [accessed 2012-02-11].

WORLD ECONOMIC FORUM, 2010. The global competitiveness report 2010-2011. Available at: http://www3.weforum.org/docs/WEF_GlobalCompetitivenessReport_2010-11.pdf [accessed 2011-08-10]. ZANATTA, M., COSTA, I. \& FILIPPOV, S. 2006. Foreign direct investment: key issues for promotion agencies. United Nations university: Policy Brief No 10:1-7. Available at: http://www.merit.unu.edu/ publications/pb/unu_pb_2006_10.pdf [accessed 2013-09-16]. 